\title{
Spanglish in contemporary music
}

\author{
Semen E. Suprunov ${ }^{1,2, *}$, Irina A. Deeney (Kuprieva) ${ }^{3,4}$, and Ekaterina Alexandrovna \\ Drozdova $^{4}$ \\ ${ }^{1}$ Plekhanov Russian University of Economics, Moscow, Russian Federation \\ ${ }^{2}$ Belgorod State National Research University, Stremyanny Lane, 36, 117997 Moscow, Russian \\ Federation \\ ${ }^{3}$ Institute of International Law and Economics named after A.S. Griboyedov, Moscow; \\ ${ }^{4}$ Institute of Foreign Languages "Peoples' Friendship University of Russia (RUDN University)", \\ Miklukho-Maklaya Str., 6, 117198 Moscow
}

\begin{abstract}
Spanglish is a unique linguistic phenomenon that is widely used in many spheres of social life and culture, especially among the youth. The relevance of this work lies in the fact that a person who wants to understand the culture of Mexico and the United States of America, to understand the speakers of the Mexican version of the Spanish language and communicate with them successfully, needs to know about the principles of using Spanglish, its significance for speakers, and also its areas of application. The subject of the research is the features of the use of Spanglish in modern music. The purpose of this paper is to study the Spanglish phenomenon and consider examples of its use by contemporary songwriters. Among the tasks it can be noted: based on the experience in studying the history of the origin of Spanglish, consider its main features, give examples of the use of Spanglish in modern musical compositions and draw a conclusion about the frequency of occurrence of Spanglish in music.
\end{abstract}

\section{Introduction}

In many studies published recently, a hypothesis has emerged that, since Spanglish is popular today among various segments of the population, including young people, it often appears in music, which is also of interest to the general public. The material for this work is the songs of Mexican and American performers who use Spanglish in their work. Based on the point of view of Mexican authors on the Spanglish phenomenon, we are trying to give a more complete understanding of the essence of the phenomenon under consideration. It is undeniable that languages throughout their existence are subject to change and mutual influence. As soon as the language stops changing, it becomes dead. Living languages are characterized by the formation of hybrid languages - the products of the interaction of several languages. One of these languages is Spanglish - a mixed language that has absorbed the features of Spanish (mainly its Mexican version) and English [6].

The emergence of Spanglish began in the middle of the 19th century after the end of the war between the United States of America and Mexico, when part of the Mexican territories came into the possession of the United States, as a result of which many Mexicans changed

\footnotetext{
${ }^{*}$ Corresponding author: suprunov.semyon@yandex.ru
} 
their citizenship and were forced to learn to speak English. These events provoked the emergence of diglossia, as Mexicans had to speak English in formal situations, while continuing to use Spanish in informal communication.

However, today Spanglish is spoken not only by residents of the border regions of Mexico and the United States, but also by other Hispanic communities living in the United States, whose residents have emigrated from Latin America. Although Spanglish is spoken throughout the United States, there are localities in which it is most commonly used: the states of California, New York, Florida, Texas and their most populous cities [1].

\section{Methodology}

The theoretical and methodological basis of the study was made up of works Mexican researchers published during the last decades. The material of the work was the songs of the performers of Mexican and of American origin, using Spanglish in their art. Research methods: study of information sources, analysis information obtained, information synthesis, induction in the analysis of private cases of Spanglish use. The basis for writing this work was the hypothesis consisting in that, since Spanglish is popular today among different layers population, including young people, he often appears in music, which is also of interest to the general public. The theoretical significance of the work is that its materials can be useful for students studying Spanish dialects and cross-cultural interactions. Moreover, this study reflects the point of view of Mexican authors on the Spanglish phenomenon, which will give more full understanding of the essence of the phenomenon under consideration. The practical significance of this study lies in the fact that that his results can be used in the study of Spanish and its national variants, as well as when studying the mutual influence of cultures, their causes and preconditions.

\section{Main part}

Language largely determines the spiritual essence and mentality of peoples, and together with other categories - such as race, geographical location, natural boundaries, common historical heritage and interests, including economic ones, the desire and consent to live together forms modern nations. It is amazing how it is possible to convey in a foreign language numerous expressions that have arisen in other languages, and which over time completely enter the fabric of the lexicon of this language. Indeed, the intensity and speed of planetary communication is increasingly moving towards the adoption and use of neologisms, including linguistic and supranational ones, accelerating the process of interpenetration of cultures and languages of different peoples who were or are in close contact with each other [23].

Many researchers are of the opinion that some of the people of Mexican descent who speak Spanglish are poor and illiterate. They use English vocabulary because they lack the vocabulary and education to adapt to their surrounding culture. At the same time, the middle class also owns Spanglish, considering it an interesting modern means of informal communication. Therefore, Spanglish is different from another type of slang, because various social groups can speak it, it does not serve certain areas of activity. The use of Spanglish is inherent in people of different social and economic backgrounds, from workers to TV presenters [2].

Moreover, Spanglish is not only a communication tool, but also a symbol of the identity of Spanish speakers living in the United States. It is also a symbol of resistance to the dominant culture, as Hispanics are the only group of immigrants who oppose the full transition to English as an official language. This phenomenon is explained by the fact that 
not only people from Mexico and other Latin American countries speak Spanglish, but also Americans who moved to Mexico [11].

In addition, Spanglish brings together the Hispanic community in the United States, strengthens its collective identity, and applies it to much of its daily life; despite the lack of standardization, it is used in various fields, including advertising, music, television, radio, as well as newspapers and magazines. According to statistics, the number of Spanglish speakers in the United States is growing [3].

In terms of structure, Spanglish lexical units can be divided into three groups:

- lexical units of a foreign language, adapted at the phonological and morphological levels;

- lexical units of a foreign language, adapted only at the phonological level;

- switching codes - combining two languages at the syntax level [7].

Phonological borrowings are bi-directional, contributing to the "spanglification" of English borrowings. Thus, words borrowed from one language are pronounced according to the phonological rules of another. In most cases, these words have equivalents in the borrowing language, but native speakers resort to borrowing in order to evoke the desired association or produce a certain effect [5].

Morphological adaptations often occur simultaneously with phonological adaptations. For example, with such adaptations, the ending typical of the Spanish infinitive is added to the English-language stem of the verb, giving rise to such forms as: telefonear - to call, parquear - to park, lunchear - to have dinner. In such cases, the infinitive ending -ar is transformed into the ending -ear by adding the vowel e [12].

Spanglish speakers often resort to code switching, alternating between Spanish and English morphemes within the same word or phrase within the same sentence. Research shows that this phenomenon cannot be accidental, since it is a complex system consisting of many models and structures [10].

Scientists agree that code switching is a sign of bilingualism [4]. It has been proven that code switching occurs at certain moments of the conversation, and, in turn, cannot occur in any situation. For example, it is not customary to mix morphemes within a word, while a change in the final morpheme, especially one that carries grammatical information, is very common [8].

Thus, switching codes in Spanglish cannot be called a random phenomenon, it is a sign of proficiency in two languages at the same time and allows you to choose language means for the most effective communication. It is believed that Spanglish has its own morphosyntax, which forms the identity not only of the individual who speaks it, but of the entire society that owns it [9].

Let's look at the use of Spanglish using examples from popular musical compositions of the last twenty years. Most often Spanglish can be found in the works of representatives of such a musical style as Chicano rap. This subgenre of hip-hop was created by the Latin American population of the western United States and northern Mexico [15]. A prominent representative of this style is the Delinquent Habits group, also known as Los Tres Delinquentes. The influence of Mexican rhythms and motives is evident in her music. Let's take a look at the lyrics from this group's song "Tres Delinquentes": "Because the huero loco came in here to play baby". This line is written primarily in English, with the exception of the phrase "huero loco", in which the word "huero" is slang. In contrast, the fragment "Otra vez ya lo vez and the crew somos tres" uses Hispanic vocabulary, while the expression "and the crew" is of English origin. Although the slang noun "crew", meaning an informal group, has leaked into many languages, including Russian, this case cannot be called a borrowing, because in addition to the noun often used by American rappers, the authors also borrowed the English conjunctive conjunction "and" and the definite article "The", which indicates that this is an illustration of the use of Spanglish. 
The following fragment is curious:

"Me I play the back role but I'm delinquente

This is how I freak it when I'm speaking to the gente

Whatcha trucha calmate escucha"

The first two lines are written in English, but their rhyming words "delinquente" (delinquent) and "gente" (people) are Spanish. At the same time, the third line begins with the word "whatcha" borrowed from the English language, a shortened version of the expression "what are you", continues its Spanish-language text.

Let's analyze the following snippet:

"Producer más mejor it's O.G. style again

Freak it bump it bass out the caro

Third of tres brings cuts to your face bro" [17]

The bulk of the text is written in English, while each line contains one Spanish word or phrase. At the same time, the Spanish-language equivalents of English words are used in the first and third lines: más mejor - much better - much better and tres - three - three. However, the second line ends with the noun "caro", a derivative of the English word "car" with an "o" at the end, necessary to give the word a more "Spanish" look and feel.

However, Spanglish cannot be called the exclusive property of rappers [14]. It is widely used by many pop singers, such as the Mexican-American singer Sophia Reyes. Consider snippets from her songs "Muévelo", "Conmigo" and "Louder!" respectively:

"Esta vida makes me happy" [22]

"We can dance in the fire, hasta que salga el sol

Burning up with desire, solitos tu y yo" [16]

"Me llevas lejos a otro lugar

Take me to this stratosphere and back" [21]

In the examples given, one half of the phrase is in English and the other in Spanish.

The use of Spanish alongside English is also characteristic of performers born in the United States, whose family once emigrated from Latin America. An example is the rapper Pitbull's song "Por Favor"

"Please, vas a tener que esperar

Yo me pillo un french kiss ...

Si lo quieres tonight" [20]

Obviously, the main language of this fragment is Spanish, but it contains words in English that everyone knows, even those who are not familiar with this language: "please"," French kiss","tonight". It is impossible to ignore the fact that the use of Spanglish in music has gone beyond the borders of the United States and Mexico; many Latin American artists who are not from these countries record their compositions on it. Such popularity of Spanglish can be explained by the orientation of Latin American artists to a Western audience, for which songs in two languages are familiar and familiar. The demand for such compositions among Western listeners is illustrated by The song " Taki Taki", performed by DJ Snake, Ozuna, Cardi B and Selena Gomez, which has won several music awards:

"Porque I am the party, yo soy fiesta

Blow out your candles, then have a siesta

They can try, pero no one can stop me" [19]

While the word "siesta" can be considered a borrowing of a foreign language reality, the expression "yo soy fiesta" and the official "porque" and" pero " have the equivalents are in English, which indicates that the authors deliberately resorted to Spanglish. Tracing papers from English are also popular among performers [13]. For example, the song of the artist AjOne "No Hace Sentido" is a calque from English "doesn't make sense " [18]. The correct Spanish version would be "no tiene sentido". 


\section{Discussion and results}

Thus, Spanglish is widely used by musicians in various forms: both by mixing the two languages, and by calculating English-language constructions and adding Spanish endings to English words. Being a popular phenomenon, it is not only a hybrid language, but also the basis of the identity of the Mexican population living in the United States of America. It is spoken by all segments of the population, including politicians who want to show that they are on the same wavelength as the people in order to get as many votes as possible. The results of this study show that Spanglish is of great importance to those who speak it. At the same time, it is also used in the mass media, which proves its prevalence. This work can be useful to anyone who studies Spanish and its variants, as well as he is planning a trip to the border areas of the United States. It was revealed that musicians performing in different genres widely use Spanglish in their compositions, thereby increasing its popularity and causing sympathy among native speakers of this language. However, the problem of the use of Spanglish in other spheres of public life requires further consideration.

\section{References}

1. A. Barro, ¿Desaparecerá el español de EE.UU. como pasó con el italiano, el alemán o el polaco? (2015)

2. S. Betti, D. y Jorques, Visiones europeas del Spanglish (2015)

3. S.Betti, E. y Serra, Nuevas voces sobre el Spanglish: una investigaciónpolifónica, 10 (2016)

4. D. Dumitrescu, Spanglish, estadounidismos y bilingüismo vestigial: ¿Qué es qué?, 26 (2015)

5. C. Hernández Sacristán, Visiones europeas del Spanglish, 41 (2015)

6. Instituto Cervantes. El español: una lengua viva, (2019)

7. D. Jorques-Jiménez, Bilingüismo y déficit de atención: tests demedición. El caso del Spanglish, 51 (2015)

8. J. Lipski, Sociolinguistic Studies, 23 (2014)

9. Á. López García-Molins, R. Morant-Marco, Visiones europeas del Spanglish, 86 (2015)

10. E. Márceles Daconte, "Spanglish: puente entre dos culturas" (2008)

11. Martínez, A. Daniel, F. Francisco Moreno Fernández, Informes del Observatorio / Observatorio Reports (2016)

12. F. Moreno Fernández, Boletín Semanal Instituto Franklin-UAH (2015)

13. Diccionario de la lengua Española, 23 (2014)

14. ¿Estás ready?: A look at "Spanglish" in the United States. Panoramas (2011) https://www.panoramas.pitt.edu

15. Chicano rap (2001) https://es.wikipedia.org

16. Conmigo (2003) https://www.letras.com

17. Delinquent Habits (2009-2020) https://genius.com

18. No Hace Sentido (2015) https://music.apple.com

19. Ozuna Tries to Seduce Cardi B and Selena Gomez in 'Taki Taki' Lyric Translation, https://www.billboard.com

20. Pitbull feat. Fifth Harmony, http://www.songlyrics.com

21. S. Reyes, LOUDER (2004) https://www.metrolyrics.com 
22. S. Reyes (2000) https://www.azlyrics.com

23. A. V. Fedorova, V. A. Martsinovskaya, Collection of articles on the materials of the interregional scientific and practical conference " Actual problems of the general theory of language, theory of literature, translation, intercultural communication and methods of teaching foreign languages", 37 (2021) 